\title{
A Conduct-Oriented Approach to the Glass-Steagall Act
}

The Glass-Steagall Act ${ }^{1}$ requires that commercial banking be separated from investment banking. ${ }^{2}$ Courts and regulatory agencies interpreting the prescribed separation often rely on technical and semantic considerations in deciding whether an investment constitutes a "security" for the purposes of the Act. ${ }^{3}$ This Note argues that such a "definitional" approach obscures the Act's purposes. ${ }^{4}$ The Note maintains that the applicable provisions of the Act are intended to bar commercial banks from engaging in a particular, identifiable pattern of conduct and that adoption of a "conduct" test for enforcement of the separation provision would serve the Act's legislative objectives better than the current approach. The Note concludes by applying these alternative approaches to a current GlassSteagall controversy-the legality of commercial banks' underwriting of commercial paper. ${ }^{5}$

1. The Glass-Steagall Act is the popular name for the Banking Act of 1933, ch. 89, 48 Stat. 162 (codified in scattered sections of 12 U.S.C.). For a general discussion of the Act, see Perkins, The Divorce of Commercial and Investment Banking: A History, 88 BANKING L.J. 483 (1971).

2. See Banking Act of 1933, $\S \S 16,21,12$ U.S.C. $\$ \S 24,378$ (1976). The Banking Act of 1933 contained many provisions of great importance to the banking system, such as those creating the Federal Deposit Insurance Corporation. The term "Glass-Steagall Act," however, has generally come to refer exclusively to the sections of the Banking Act that pertain to commercial banks' securities activities. Section 16 of the Glass-Steagall Act approaches the Banking Act's legislative goals from the perspective of the commercial banker and $\S 21$ approaches the legislative goals from the perspective of the investment banker. Section 16 prohibits commercial banks from engaging in "underwriting" or investment banking while $\S 21$ bars organizations "engaged in the business of issuing, underwriting, selling or distributing" securities from receiving deposits. Board of Governors of Fed. Reserve Sys. v. Investment Co. Inst., $101 \mathrm{~S}$. Ct. 973, 976 (1981). This Note addresses the $\S 16$ congressional concerns of commercial bank activity in the investment banking field.

3. See Karmel, Glass-Steagall: Some Critical Reflections, 97 BANKING L.J. 631, 633, 634 (1980) (Glass-Steagall characterizes banking activity as permissible or impermissible on basis of whether a security is involved in the transaction); Plotkin, What Meaning Does Glass-Steagall Have for Today's Financial World? 95 BANKING L.J. 404, 411 (1978).

4. See Keeffe, Your Friendly One Stop Financial Shopping Center, 60 A.B.A. J. 744, 745 (1974).

5. Commercial bank activity in the commercial paper market began on July 26,1978 , when Bankers Trust Company, a state bank member of the Federal Reserve System, started selling commercial paper of corporations to investors. See H. Pitt \& J. Kempner, The Commercial Paper Activities of Bankers Trust Company 1-2 (January 31, 1979) (unpublished memorandum on behalf of A. G. Becker Inc. to the Staff of the Board of Governors of the Federal Reserve System on file with Yale Law Journal). 


\section{The Purposes of the Glass-Steagall Act}

Congress enacted the Glass-Steagall Act for two purposes. First, and most importantly, it sought to eliminate the conflicts of interest that arise when commercial banks engage in the sale of securities. ${ }^{6}$ Second, it sought to prevent loss of public confidence in the banking system, which had led to runs on banks and to bank failures at the start of the Great Depression. ${ }^{7}$

Congress found these problems so compelling that it chose to prohibit banks from engaging in both commercial and promotional activities altogether, rather than just to regulate their activities when they engaged in both businesses. Besides the original Congressional purposes behind Glass-Steagall, however, today the Act serves the additional, important purpose of decentralizing investment activity. ${ }^{8}$

Glass-Steagall safeguards restrict competition between investment and commercial banks, but even the most procompetitive commentators acknowledge that the fiduciary responsibilities of commercial banking operations present unavoidable conflicts of interest with the promotional operations of corporate investment banking. 'Thus, any competitive benefits that would arise from commercial bank entry into investment banking are outweighed by the "hazards" and "financial dangers" posed by allowing commercial banks to underwrite securities. ${ }^{10}$

6. See Board of Governors of Fed. Reserve Sys. v. Investment Co. Inst., 101 U.S. 987 (1981); Investment Co. Inst. v. Camp, 401 U.S. 617, 633 (1971); 75 CONG. REG. 9912 (1932) (remarks of Sen. Bulkley).

7. See Board of Governors of Fed. Reserve Sys. v. Investment Co. Inst., 101 S. Ct. 973, 984 (1981); S. REP. No. 77, 73d Cong., 1st Sess. 6, 8, 10 (1935); 77 CoNG. REC. 3825 (remarks of Rep. Glass); Plotkin, supra note 3, at 407; Note, The Legality of Bank Sponsored Investment Services, 84 YALE L.J. 1477, 1487 (1975).

8. The Glass-Steagall Act continues to have a great deal of vitality today, over fifty years after its enactment. See Board of Governors of Fed. Reserve Sys. v. Investment Co. Inst., 101 S. Ct. 973, 991 n.55 (1981). The legislative history of The Bank Holding Amendments Act of 1970, Title I, 84 Stat. 1763, indicates that Congress intended the Amendments to reinforce Glass-Steagall. 116 CONG. REC. 42,430 (1970) (remarks of Sen. Williams).

9. See UNITED STATES PRESIDENT'S COMM'N, THE REPORT OF THE PRESIDENT'S COMMISSION ON FINANCIAL STRUCTURE AND REGULATION 52 (1971) [hereinafter cited as U.S. PRESIDENT's COMMISSION REPORT]. The Commission's prime objective was to increase competition among financial institutions. See id. at 121 .

Competition may actually be enhanced, however, by separating investment banking from commercial banking. Although commercial banks and investment banks may not offer the same services, they do offer substitutable services. The enforced separation of commercial and investment banking places pressure on each market to innovate in order to compete with the other. The growth of the commercial paper market is an example of the beneficial aspects of bifurcated markets. Commercial paper is an investment banking product that competes with the corporate lending services of commercial paper. See p. 115 infra; Stephen J. Friedman, Investment Management and the Glass-Steagall Act — The Emperors' New Clothes 5 (November 13, 1980) (unpublished remarks to Association of Bank Holding Companies) (on file with Yale Law Journal); of. Bennett, Corporate Loans Soar at Banks, N.Y. Times, December 16, 1980, $\S \mathrm{D}$ (Business), at 12, col. 1 (commercial banks are "aggressively cutting prices to compete for business with the commercial paper market").

10. This was the view when Glass-Steagall was passed. See Investment Co. Inst. v. Camp, 401 


\section{A. Conflicts of Interest}

The Act's prohibition of commercial bank underwriting ${ }^{11}$ was also meant to encourage commercial banks to render strictly impartial advice to depositors, correspondent bankers, and other customers. Congress recognized the inherent conflict between the commercial banking role of impartial advisor and the investment banking role of promotional underwriter. ${ }^{12}$ Commercial bankers routinely advise corporate clients about whether their corporations should issue debt and about the best structure and timing of debt issues. ${ }^{13}$ Congress did not want the impartiality of this advice to be tainted by a desire to profit from the promotion of one particular security over another. ${ }^{14}$ Congress wanted this investment advice to be based solely on sound business judgment and to be free of promotional incentives such as sales or distribution commissions. ${ }^{15}$

Investment banks, however, sell securities ${ }^{16}$ and promote the debt obligations of third parties in order to earn sales or distribution commissions. Commercial banks therefore face conflicts of interest when they engage in investment banking because of the different institutional roles played by commercial and investment banks.

One set of conflicts arises when the commercial bank attempts to convince corporate customers to make public offerings of securities through the bank. Investment banks require a continuous supply of securities in order to maintain distribution channels, which are difficult and expensive to develop. ${ }^{17}$ These distribution channels comprise the most important part of the investment banker's service. The drafters of Glass-Steagall realized that a commercial banker cannot render impartial advice about the

U.S. 617, 630 (1971). It remains the prevailing view today. See U.S. PRESIDENT's COMIIISSION REPORT, supra note 9 , at 52 ; note 28 infra.

11. See note 40 infra.

12. Investment Co. Inst. v. Camp, 401 U.S. 617, 634 (1971).

13. Members of the Glass-Steagall Congress recognized that corporate treasurers rely heavily on the advice of commercial bankers to solve intricate business problems. See 75 CONG. REC. 9912 (1932) (remarks of Sen. Bulkley). Congress sought to construct a financial system in which the commercial banker could be regarded as "confidant and mentor" of his depositors. This relationship was viewed as natural and desirable for both the small depositor and the "great corporation." Id.

14. 75 CONG. Rec. 9912 (1932) (remarks of Sen. Bulkley).

15. A Resolution to Make a Complete Survey of the National and Federal Reserve Banking Systems: Hearings on S. Res. 71 Before the Subcomm. of the Senate Comm. on Banking and Currency, 71st Cong., 2d Sess. 1052 n.24 (1931) (remarks of Rep. Glass) (congressional goal of preventing commercial banks from "merchandising" securities); 75 CONG. REC. 9912 (1932) (remarks of Sen. Bulkley).

16. Investment banking by definition consists of underwriting and selling stocks and bonds. An investment banker is an underwriter who serves as a "middleman" between the corporation issuing securities and the investors who purchase them.

17. Congress recognized at the time Glass-Steagall was passed that it was unreasonable to expect a banker to give impartial investment advice after developing expensive securities distribution systems. Practical business considerations lead inexorably to the biased promotion of those securities in inventory. 75 CONG. REC. 9911 (1932) (remarks of Sen. Bulkley). 
"necessity and soundness" of a new securities issue if he or she has an incentive to feed the costly distribution channels ${ }^{18}$ that the bank has so expensively developed, and that can absorb the new security issue and make a distribution profit for the bank whether or not the issue is needed by the issuer. ${ }^{19}$ Prohibiting commercial banks from engaging in investment banking activities alleviates the temptation to exert undue pressure on the corporate customer to issue a security. ${ }^{20}$

A second set of conflicts results from the temptation banks have to promote a securities issue so that the issuing corporation can use the proceeds to repay bank loans or to pay down bank lines of credit. ${ }^{21}$ This problem is particularly serious during periods of high interest rates, when the cost of issuing certain securities is low relative to commercial banking rates.

A third conflict of interest problem is that the commercial bank's stake in an investment banking venture may lead it to make unsound loans or credit advances ${ }^{22}$ to companies whose securities it is promoting. The borrowing costs of issuing a debt security are closely linked to the credit rating assigned to that security; the better the rating, the lower the interest rate. ${ }^{23} \mathrm{~A}$ bank that grants a large back-up line of credit to a corporation improves the company's credit rating and aids the underwriter in the sales of the company's debt. ${ }^{24}$ If commercial banks could conduct an underwriting business, they might be tempted to make unsound loans to the firms whose securities they were promoting.

Separating investment from commercial banking, on the other hand,

18. Congress acted to keep commercial banks out of investment banking because the "promotional incentives" and "pecuniary stakes" in the success of particular investment opportunities were destructive of prudent commercial banking. S. REP. No. 77, 73d Cong., Ist Sess. 8 (1925); 75 CONG. REC. 9911 (1932) (remarks of Sen. Bulkley).

19. 75 CONG. REC. 9911 (1932) (remarks of Sen. Bulkley). Senator Bulkley's remarks have been treated as authoritative by courts, in part because he was addressing Congress on the subject of the separation of commercial and investment banking at the specific request of the chairman of the Senate Banking Committee, Senator Glass. 75 CONG. REC. 9909 (1932) (remarks of Sen. Bulkley).

20. 75 CONG. REC. 9912 (1932) (remarks of Sen. Bulkley). One reason that some members of Congress did not want commercial banks to exert this promotional pressure was to protect the corporation from issuing too much debt. Id. at 9911.

21. Id.; Telephone interviews with Patrick Doyle, Counsel to the Multinational Banking Division, Law Department, Comptroller of the Currency (October 17, 1980 \& December 12, 1980). A bank line of credit is a fixed amount of credit extended by a bank to its customer to cover a series of transactions. The customer may avail himself of this amount at any time. When the customer's line of credit is nearly exhausted, he is expected to reduce his indebtedness by payments to the bank before drawing upon it further.

22. Investment Co. Inst. v. Camp, 401 U.S. 617, 637 (1971) (bank's stake in issuing corporation might distort credit decisions).

23. See Hurley, The Commercial Paper Market, 63 FED. RES. BULL. 526, 529 (1977); Letter from Bankers Trust Company to an anonymous commercial paper issuer (November 21, 1978) (on file with Yale Law Journal) (most important consideration in entering commercial paper market is having top ratings).

24. See Harries, How Corporate Bonds and Commercial Paper Are Rated, Financul ExecuTIVE, September 1971, at 30. 
provides an "independent and impartial check" on the soundness of the promotional security. ${ }^{25}$ This impartial check occurs regularly because a commercial bank typically makes a credit check of a corporation that is planning to issue securities for the purpose of determining whether to extend a back-up line of credit. ${ }^{26}$ This line of credit has become a "traditional safeguard of the market" ${ }^{27}$ because it provides additional insurance to the purchaser of the corporate debt that the obligation will be repaid.

\section{B. Bank Stability}

Congress was convinced that banks' speculative securities promotion ${ }^{28}$ and perilous underwriting activities ${ }^{29}$ led to the loss of depositor confidence and customer good will that caused the depression era bank runs. ${ }^{30}$ The Federal Deposit Insurance Corporation, which was created by the Banking Act of 1933, effectively halted runs on banks and thereby mitigated most depositors' risk of loss from bank failures. ${ }^{31}$ Thus, the conflicts of interest arising from commercial bank investment banking activity provide the most compelling basis for Glass-Steagall's continued support in Congress $^{32}$ and the courts. ${ }^{33}$ The Glass-Steagall Act's prohibition of commercial bank underwriting was designed to promote bank stability by supplementing the role played by deposit insurance in achieving public confidence in the commercial banking system. The Glass-Steagall Act was also

25. 75 CONG. REC. 9912 (1932) (remarks of Sen. Bulkley).

26. See Note, Commercial Paper and the Securities Acts, 39 U. CHI. L. REv. 367, 372 (1972).

27. J. Light \& W. WHITE, THE FinANCIAL SYSTEM 281 (1979); see Loomis, The Lesson of The Credit Crisis, FORTUNE, May 1971, at 141, 143 (commercial bank lines of credit prevented collapse of commercial paper market in 1970).

28. Board of Governors of Fed. Reserve Sys. v. Investment Co. Inst., 101 S. Ct. 973, 984 (1981), slip op. at 14, (February 24, 1981). See S. REP. No. 77, 73d Cong., lst Sess. 6, 10 (1935); 77 ConG. REC. 3907 (1933) (remarks of Rep. Koppleman); 77 CONG. REC. 3835 (1933) (remarks of Rep. Glass).

29. See S. REP. No. 77, 73d Cong., lst Sess. 10 (1933); 77 CONG. REC. 3835 (1933) (remarks of Rep. Glass).

30. See Hearings on the Operation of the National and Federal Reserve Banking System: S. Res. 71 Before the Banking Subcomm. of the Comm. on Banking and Currency, 71st Cong., 3d Sess. 116, 117, 1017, 1068 (1931) [hereinafter cited as 1931 Hearings]; 75 CONG. REC. 9912 (1932) (remarks of Sen. Bulkley) (commercial bank may be put in financial danger); Lybecker, Bank Sponsored Investment Management Services: A Legal History and Statutory Interpretive Analysis - Part I, 5 SEC. REG. L.J. 110, 129 (1977) (extensive failure of banks in wake of stock market crash of 1929).

31. See U.S. PRESIDENT'S COMMISSION REPORT, supra note 9, at 44. Federal deposit insurance coverage is limited to $\$ 40,000$ per account per bank. Among the losses not covered are losses on securities purchased from member banks.

Federal deposit insurance does not actually prevent bank failures. When failures occur, there is a delay that prevents the depositor from gaining immediate access to his money. [1979] FED. DEPOSIT INS. CORP. ANN. REP. 14-15, 49-60, 131.

32. Congress intended the recent Bank Holding Company Act to strengthen and maintain GlassSteagall's restrictions on the relationship between commercial and investment banking. Board of Governors of Fed. Reserve Sys. v. Investment Co. Inst., 101 S. Ct. 973, 988 (1981).

33. See Investment Co. Inst. v. Camp, 401 U.S. 617 (1971); Board of Governors of Fed. Reserve Sys. v. Investment Co. Inst., 101 S. Ct. 973 (1981). 
intended to promote bank stability by preventing commercial banks from being discredited by adverse reactions to promotional, investment banking activity. ${ }^{34}$

\section{Prohibition vs. Regulation}

Congress heard much debate over whether the problems posed by commercial banks' securities activities should be solved by regulation or prohibition. ${ }^{35}$ It chose outright prohibition because its policy objectives could not be achieved through regulation. ${ }^{36}$ It considered regulation to be ineffective because the problems and conflicts inherent in commercial bank participation in the promotion of securities are "so subtle as not to be easily recognized, ${ }^{37}$ and because securities underwriting is fundamentally incompatible with commercial banking. ${ }^{38}$ The universally recognized means for achieving Congress's objectives was to separate commercial banking from investment banking. ${ }^{39}$ The separation was accomplished through section $16,{ }^{40}$ which limits national banks' purchases and sales of securities to agency executions made solely on a customer's order, and through section $21,{ }^{41}$ which makes it unlawful for investment banks to

34. The recent New York City financial crisis exemplifies how promotional investment activity can discredit banks and thus weaken their stability. Commercial banks are permitted by $\$ 16$ of the Glass-Steagall Act to underwrite municipal bonds. See p. 109 infra. New York City's commercial banks became deeply involved in the events leading to the city's financial crisis, and were at the center of the controversy because of their allegedly disreputable conduct and motives in dumping deflated New York City bonds on unsuspecting bank customers. N.Y. Times, July 29, 1975, § 1, at 1, col. 6.

35. See Hearings on S. Res. 71 Before the Subcomm. on Banking of the Senate Comm. on Banking and Currency, 71st Cong., 3d Sess., Pt. 1, at 19-22 (testimony of J. W. Pole, Comptroller of the Currency); id. at 191-92 (testimony of Albert H. Wiggin, Chairman of the Board, Chase National Bank); id. at 238-41 (testimony of B. W. Trafford, Vice-Chairman, First National Bank of Boston); id. Pt. 2, at 301-04, 318 (testimony of Charles E. Mitchell, Chairman of the Board of National City Bank of New York); id. Pt. 2, at 356, 364-65 (testimony of Owen D. Young, Chairman of the Board, General Electric Co.); id. Pt. 3, at 539 (testimony of Allan M. Pope, Executive Vice-President of First National-Old Colony Corp.).

36. Even those witnesses who opposed the complete separation of commercial and investment banking favored regulation of commercial banks' securities activities. See Perkins, supra note 1, at 506.

37. 75 CONG. REC. 9912 (1932) (remarks of Sen. Bulkley). The Supreme Court has pointed out that Congress "repeatedly focused on the more subtle hazards" that arise when a commerical bank goes beyond the business of acting as fiduciary agent and enters the field of investment banking. Investment Co. Inst. v. Camp, 401 U.S. 617, 630 (1971).

38. See 75 CONG. REC. 9912 (1932) (remarks of Sen. Bulkley) (mere existence of commercial bank securities operation "no matter how carefully and conservatively run is inconsistent with the best interests of the bank as a whole"); Perkins, supra note 1, at 506, 507 (same).

39. See Board of Governors of Fed. Reserve Sys. v. Investment Co. Inst., 101 S. Ct. 973, 984-85 (1981).

40. Section 16 of the Banking Act of 1933, 12 U.S.C. $\$ 524$ (seventh) (1976), provides that: The business of dealing in securities and stock by . . . the [national bank] shall be limited to purchasing and selling such securities and stock without recourse, solely upon the order, and for the account of customer, and in no case for its own account, and the [national bank] shall not underwrite any issue of securities or stock.

41. Section 21 of the Banking Act of 1933, 12 U.S.C. $\S 378(a)(1)(1976)$, provides that: 


\section{The Decentralization Function of the Glass-Steagall Act}

Analysis of the current function of the fifty-year-old Glass-Steagall Act raises issues that were not considered by the original drafters. ${ }^{43}$ Principal among these concerns is whether the Glass-Steagall Act prevents an undue concentration of capita ${ }^{44}$ or of authority over capital allocation decisions. ${ }^{45}$ Today, Glass-Steagall serves the important political and economic function of decentralizing both capital formation and investment decisionmaking. ${ }^{46}$

Decentralization requires limits on the activities of commercial banks, ${ }^{47}$ which, because they dispense credit, have an inherent competitive advantage over other entities that perform the same services. ${ }^{48}$ Customers often prefer to give business to a bank that can loan money, even if the bank's price is higher than ${ }^{49}$ or its performance inferior to ${ }^{50}$ that of non-bank competitors. Customers think that they will have easier access to credit if

[It shall be unlawful] for any person, or . . organization, engaged in the business of issuing, underwriting, selling, or distributing . . . stocks, bonds, debentures, notes, or other securities, to engage at the same time ... in the business of receiving deposits.

42. An example of a $\S 21$ controversy involves money market mutual funds that are offered by investment banks. Customers of these funds earn high interest rates on accounts against which they may write checks. Commercial banks contend that these money market funds violate $\S 21$ of GlassSteagall. See N.Y. Times, March 3, 1981, § D (Business), at 1, col. 3; BUS. WEEK, March 2, 1981, at 49.

43. See Karmel, supra note 3, at 632 .

44. See R. Schotland, What Issues Are Alive in Glass-Steagall Today? 3 (March 24, 1977) (unpublished address at Golembe Associates seminar on Competition in Banking, Chicago, Illinois) (on file with Yale Law Journal) (danger that American financial community could become as heavily concentrated as its Japanese counterpart).

45. See Hearings on Bank Holding Company Amendments Before the House Comm. on Banking and Currency, 91st Cong., 1st Sess. 36 (1969).

46. WeEkly COMPILATION OF PREsidentinl DocumenTs, March 24, 1969, at 461. Banking trends, if left unchecked, may lead to formation of a small number of power centers that dominate the economy, a result that federal banking policy has long opposed. Id. One reason for this opposition is that excessive concentration weakens the capitalist system by eliminating the smaller businesses that are its political first line of defense. See J. SCHUMPETER, CAPITALISM, SOCInLISM AND DEMOCRACY 140 (2d ed. 1962); Taylor, Commercial vs. Investment Banks, The Case Against, 55 H^RV. BuS. REV. 138, 144 (1977). But see Angermueller, Commercial vs. Investment Banks, The Case For, 55 HARV. BUS. REV. 132, 132; Schotland, supra note 44, at 3. The ideal of decentralization stems from a desire to avoid what Arthur Burns, former Chairman of the Federal Reserve Board, describes as the "Zaibatsu problem," a situation in which economic power is concentrated in a few giant power centers as in Japan. Hearings on Bank Holding Company Amendments Before the House Comm. on Banking and Currency, 91st Cong., 1st Sess. 36 (1969) (testimony of Arthur Burns).

47. See Schotland, supra note 44, at 3 . From an historical perspective, Glass-Steagall is part of a long-standing American policy that the capital markets must remain diverse.

48. See 125 CONG. REC. 236 (1979) (remarks of Sen. Proxmire).

49. Id.

50. See PENSIONS AND INVESTMENTS, January 1, 1979, at 6 (corporate clients have retained commercial ties with poorly performing banks because of fear that corporate relations will be jeopardized if they dismiss banks). 
they buy the other services of the bank,,$^{{ }^{1}}$ and this perception leads to "coerced or voluntary" tie-in sales. ${ }^{52}$ This advantage has consistently led to commercial bank dominance in those areas of the capital market that they have been able to penetrate. ${ }^{53}$

\section{The Current Interpretation of Glass-Steagall}

The decentralization function and the congressional objectives behind Glass-Steagall are currently being thwarted because the fixed, historical definitions presently employed cannot keep pace with the rapidly evolving capital markets. Since the passage of Glass-Steagall, new securities have been created $^{54}$ and old securities have changed dramatically in character.;5 even the securities markets themselves have changed. ${ }^{56}$

\section{A. The Language of the Statute}

Section sixteen ${ }^{57}$ is the foundation ${ }^{58}$ of the Glass-Steagall Act, and the focal point of the current interpretation of the Act. ${ }^{59}$ Section 16 divides the permissible areas of commercial bank securities into three categories and provides rules of conduct for each category. First, it allows commercial banks to buy, sell, or underwrite United States government debt and general obligations of states and municipalities. ${ }^{60}$ This provision is unambiguous and has required little clarification: ${ }^{61}$ it permits banks to deal in debt obligations that are subject to the general taxing power of a government entity. ${ }^{62}$ Second, section sixteen creates a sub-category of securities known as "investment securities." for their own account, but may not underwrite, distribute, sell, or deal in

51. 125 CONG. REC. 236 (1979) (remarks of Sen. Proxmire).

52. Id.

53. See Perkins, supra note 1 , at 495-96.

54. Karmel, supra note 3, at 636; see Note, supra note 7, at 1490 (term "security" now applied to everything from interests in condominiums to warehouse receipts).

55. See Note, supra note 26 , at 374 .

56. See Friedman, supra note 9 , at 2 . Significant changes include the use of short term obligations to finance long term capital needs, modern cash management systems, securities issued for arbitrage purposes, and the continuous "roll-over" of debt obligations.

57. See note 40 supra.

58. Karmel, supra note 3, at 633.

59. The current interpretation of Glass-Steagall focuses on defining the term "security." See note 71 infra; Karmel, supra note 3, at 633-34.

60. The limitations and restrictions herein contained as to dealing in, underwriting and purchasing for its own account, investment securities shall not apply to obligations of the United States, or general obligations of any State or of any political subdivision thereof.

12 U.S.C. \& 24 (seventh) (1976).

61. The clarity of the provision has resulted in a paucity of litigation on the subject. See Baker, Watts \& Co. v. Saxon, 261 F. Supp. 247, 252 (D.D.C. 1966), aff', 392 F.2d 497 (1968).

62. The government debt exception rests on long-standing public policy favoring governmental debt obligations. Baker, Watts \& Co. v. Saxon, 261 F. Supp. 247, 252 (D.D.C. 1966).

63. See 12 U.S.C. $\$ 24$ (seventh) (1970). 
them. The Comptroller of the Currency has statutory authority to decide which debt instruments fall in this category, ${ }^{64}$ and few problems arise in this area. ${ }^{65}$ Third, section sixteen permits banks to buy or sell any security without recourse, solely on the order of and for the account of customers. ${ }^{66}$ This agency exception was enacted to enable banks to service communities far from financial centers. ${ }^{67}$

Similarly, banks may engage in private placements of securities without violating Glass-Steagall. ${ }^{68}$ Private placements, which may be offered only to a small number of sophisticated investors, ${ }^{69}$ do not constitute "underwriting" within the terms of Glass-Steagall because they do not involve a "distribution" of securities."

\section{B. The Present Interpretation of the Statute}

The current approach to resolving Glass-Steagall controversies involves two steps. It first requires a definition of the word "security."71 Because

64. Id.

65. Congress allows banks to purchase investment securities for their own account to provide a means to satisfy the reserve asset requirement of the Federal Reserve Board.

66. 12 U.S.C. $\$ 24$ (seventh) (1976).

67. See Hearings on H.R. 5357 Before the House Comm. on Banking and Currency, 74th Cong., 1st Sess. 663 (1935). The agency exception was introduced into Glass-Steagall in 1935 by an amendment proposed by the Comptroller. H.R. REP. NO. 742, 74th Cong., 1st Sess. 16 (1935); S. REP. NO. 10007, 74th Cong., 1st Sess. 15 (1935).

68. Federal Reserve Board Staff, Commercial Bank Private Placement Activities (June 1977) (unpublished staff report on file with Yale Law Journal). A private placement, also known as a direct placement, is an alternative to an open-market sale of securities. A private placement consists of direct negotiation of a debt obligation between a corporate borrower and an institutional investor. C. HENNING, W. PIGOTT, R. SCOTT, FINANCIAL MARKETS AND THE ECONOMY 296 (2d ed. 1978).

The exception for private placements is consistent with the general policies of the Glass-Steagall Act and therefore with the conduct approach suggested in this Note. A private placement conducted by a bank must conform with the restrictions of $\S 16$. The commercial bank can act only as an agent, in a non-recourse transaction initiated on a customer's order. See Federal Reserve Board Staff, supra (June 1977) (unpublished staff report on file with Yale Law Journal). The issue of whether banks are engaged in "private placements" of securities can best be resolved by examining the conduct of the commercial bank.

69. See SEC v. Ralston Purina Co., 346 U.S. 119 (1953). Private placements are only available to persons who have the same information regarding the issuer that registration would provide, and who are able to fend for themselves. Id. Private placements were intended to permit an issuer to make an isolated, specific sale of securities to a single person. R. JENNINGS \& H. MARSH, SECURITIES REGULATION 410 (4th ed. 1977).

70. Cf. 1 LOSS, SECURITIES REGULATION 653-54 n.43 (2d ed. 1961) (there is no underwriting in private placement because there is no distribution); Comptroller of the Currency, Federal Deposit Insurance Corporation, \& Federal Reserve Board, Commercial Bank Private Placement Activities 4 (June 1, 1978) (unpublished staff report on file with Yale Law JournaI).

71. Karmel, supra note 3 , at 632 .

One version of the definitional approach is to apply to Glass-Steagall controversies the definition of "security" used in the Securities Act of 1933 , ch. 38,48 Stat. 74 (current version at 15 U.S.C. $\$ \S 77 \mathrm{a}-$ 77aa (Supp. II 1978)). See Letter from Ralph C. Ferrara, General Counsel, Securities and Exchange Commission, to Neal L. Petersen, General Counsel, Board of Governors of the Federal Reserve System 3 (April 20, 1979) (on file with Yale Law Journal). The rationale for employing the Securities Act definition for Glass-Steagall purposes is that the two laws were enacted within a few weeks of each other and the Senate Committee on Banking and Finance was responsible for both pieces of 
Glass-Steagall applies only to "securities," the Act is not violated if no security is involved..$^{72}$ If the debt instrument in question is found to be a security, an inquiry is then made into whether the bank is underwriting, trading, or dealing in the security.

The current method of resolving Glass-Steagall disputes may lead to underinclusive results. This underinclusiveness is exemplified by the commercial-paper controvery, in which the Federal Reserve Board gave an arbitrary, narrow reading to the word "security" and thus permitted activity that the Act was intended to preclude. ${ }^{73}$ The current interpretation could result in an overly broad reading of the term security, which could lead to the proscription of legitimate commercial banking activity. ${ }^{74}$

In addition, the present method of interpreting Glass-Steagall results in the drawing of legal distinctions between interchangeable terms such as "loan" and "security," distinctions that do not arise from the policy objectives of the Act. These legal distinctions are formalistic fictions. As investors and financial markets have evolved and become more sophisticated, market participants increasingly have come to view both securities and loans merely as financing vehicles, and traditional definitional distinctions between them as matters of form rather than of substance. ${ }^{76}$

Under the current interpretation of the Act, the securities markets

legislation. But this definitional approach is unacceptable because it does not recognize that the GlassSteagall Act and the Securities Act of 1933 were enacted for different purposes. The former act was intended to stop the commercial banking abuses and conflicts that led to the bank failures of the Depression. See pp. 103-107 supra. The latter act was designed to regulate the distribution and underwriting activities of investment banks. National Ass'n of Sec. Dealers, Inc. v. SEC, 420 F.2d 83, 89 (D.C. Cir. 1969); Lydecker, Bank Sponsored Investment Management Services: A Legal History and Statutory Interpretive Analysis (pt. 2), 5 SEC. REG. L.J. 195, 207-08 (1978). Permissible banking activity under Glass-Steagall is determined by "semantical characterization" of whether debt instruments constitute securities.

72. See Karmel, supra note 3, at 632; Federal Reserve System, Statement Regarding Petitions to Initiate Enforcement Action 24 (September 26, 1980) (unpublished) [hereinafter cited as Federal Reserve Statement].

73. See pp. 115-17 infra.

74. Examples of legitimate commercial banking devices that could fall prey to erroneous interpretations of Glass-Steagall are loan participations, bankers acceptances, and certificates of deposit. See pp. 119-20 infra.

75. The terms are interchangeable because loans and securities serve the same purpose. Both are mechanisms for raising money at a certain price, or interest rate. With either instrument, the creditor gives value in the hope of gain in the form of interest paid by the borrower. See Exchange Nat'l Bank v. Touche Ross \& Co., 544 F.2d 1126, 1136-37 (2d Cir. 1976); C.N.S. Enterprises, Inc. v. G. \& G. Enterprises, Inc., 508 F.2d 1354, 1359 (7th Cir.), cert. denied, 423 U.S. 825 (1975); Fitzgibbon, What is a Security? - A Redefinition Based on Eligibility to Participate in the Financial Markets, 64 MINN. L. REV. 893 (1980); cf. I L. Loss, supra note 70, at 455 n.1 ("Even such terms as 'stock' and 'bond' do not have altogether fixed meanings .... . [Some] instruments . . . 'defy classification." "); Friedman, supra note 9, at 2 (evolution of securities markets has "outpaced" current banking regulations).

76. See Fitzgibbon, supra note 75 , at 937 . The statutory definitions of the term "security" that are currently used to implement the securities laws of the 1930's are largely denominative. As a result, there is considerable confusion about the meaning of the term. 
shape the laws; the laws do not shape the securities markets. ${ }^{77}$ The lack of a principled approach to Glass-Steagall disputes threatens to subvert the goals of the Act by obscuring those provisions that have continuing vitality and preserving only those "regulatory remnants" that are used exclusively to protect market participants from competition. ${ }^{78}$

\section{The Conduct Test}

This Note proposes a "conduct" test for resolving Glass-Steagall disputes. Unlike the current approach that categorizes debt instruments as securities in a rigid fashion, the conduct test analyzes the conduct of the bank in order to determine whether the activity is to be proscribed. This shift prevents regulatory agencies from ignoring, as they currently do, the purposes and policies behind Glass-Steagall. ${ }^{79}$ The conduct test provides a principled way of resolving Glass-Steagall disputes because it is derived from the policies underlying the Act. ${ }^{80}$

\section{A. Statement of the Test}

The universally recognized purpose of Glass-Steagall is to separate commercial from investment banking. To achieve this purpose, it is necessary to determine whether the commercial bank is engaging in a pattern of investment banking conduct. Specifically, such conduct entails establishing a sales network for the distribution of debt or equity instruments of third parties, and promoting the sale of those instruments through that network. In most cases, conduct that violates section sixteen also entails active solicitation of corporate ${ }^{81}$ issuers to support this sales distribution system.

The described conduct cannot be construed as permissible, traditional commercial bank lending activity. ${ }^{82} \mathrm{~A}$ bank engaged in such conduct does not stand to profit from the interest payments of a corporate borrower, nor

77. Friedman, supra note 9 , at $2-3$.

78. See id at 3.

79. Cf. Federal Reserve Statement, supra note 72, at 25 (unnecessary to examine the policies of the Act because "stronger view" is that commercial paper is not a security).

80. See United Hous. Foundation, Inc. v. Forman, 421 U.S. 837, 848-49 (1975) (quoting Church of the Holy Trinity v. United States, 143 U.S. 457, 459 (1892)). Because securities transactions are economic in character, "application of the statutes should turn on the economic realities underlying the transaction and not on the name appended thereto." Id. at 848 (emphasis added) (quoting Teherepnin v. Knight, 389 U.S. 332, 336 (1967)).

81. Most government debt is excluded from the proscriptions of the Glass-Steagall Act and therefore from the conduct test. See p. 109 supra.

82. The validity of analyzing a commercial bank's conduct in order to resolve disputes under $\S 16$ of the Glass-Steagall Act was recently recognized in A. G. Becker v. Board of Governors of Fed. Reserve Sys., No. 80-2614, slip op. at 21-22 (D.D.C., filed Oct. 14, 1980). Unlike this Note, however, the court did not advocate abandoning the traditional, definitional approach to resolving Glass-Stcagall disputes. See id. at 14-15, 22. 
does it stand to lose if the corporation fails to repay the principal. Instead, its only function is to act in a promotional capacity. Therefore, the bank is engaging in impermissible investment banking conduct. ${ }^{83}$

Implementation of the conduct test changes the two-step approach ${ }^{84}$ currently taken by the Federal Reserve Board and other regulatory agencies in resolving Glass-Steagall controversies. ${ }^{85}$ The proposed test combines the two steps and shifts the initial focus of analysis to the conduct of the bank. Very simply, if a bank has established a distribution system and is earning distribution commissions from the sale of the liabilities of another corporation, it is engaged in conduct that Glass-Steagall should prohibit.

\section{B. The Conduct Test and the Congressional Objectives of Glass-Steagall}

The conduct test limits the activities of commercial banks to conduct that is in accordance with the objectives of the Act. The test insures that commercial banks do not engage in the promotional aspects of investment banking.

\section{The Conflicts of Interest}

The conduct test ensures that commercial banks will render impartial investment advice by removing the incentive to promote securities held by institutions engaging in investment banking. The test distinguishes the impermissible promotion of a debt instrument solely to earn a distribution commission from the permissible banking practice of acting as a financial principal. ${ }^{86}$ Congress sought to prevent banks from forming, developing,

83. Loan participations and private placements are examples of permissible commercial banking conduct because in those transactions the banks do not function as promotional middlemen.

In a typical loan participation, a "lead bank" will negotiate a loan that is so large that it represents an uncomfortably high, if not impermissible, proportion of the bank's total assets. To reduce its exposure, the bank will "sell" participations to other commercial banks and financial institutions. In more than $99 \%$ of loan participations, the lead bank keeps the largest asset share for itself. Interviews with Patrick Doyle, supra note 21. In a minute fraction of cases, the lead bank will "sell" the entire amount of the loan to other institutions. This usually occurs when a small, regional bank has already loaned its customer the full legally permissible amount. In such a case, loan participations are distributed by the customer's banker as a service. Id.

Loan participations are considered securities for purposes of both the Securities Act of 1933, 15 U.S.C. $\$ \S 77 \mathrm{a}-77 \mathrm{aa}$ (1976), and the Securities Exchange Act of 1934, 15 U.S.C. $\$ \S 78 \mathrm{a}-78 \mathrm{kk}$ (1976). See Lehigh Valley Trust Co. v. Central Nat'l Bank, 400 F.2d 989 (1969).

Commercial bank private placement activity also does not violate the conduct test. Debt instruments that are privately placed may only be offered to a small number of investors; consequently, no sales distribution network is established, and the conduct test is not violated.

84. See pp. 110-11 supra.

85. The Securities and Exchange Commission uses a two-step approach in which the first (definitional) step involves determining whether the debt instrument is a security for the purposes of the Securities Act of 1933. See note 73 supra.

86. The Glass-Steagall Act itself describes permissible commercial banking activities. It states that commercial banks may "exercise . . . all such incidental powers as shall be necessary to carry on the 
or promoting expensive distribution networks for investments. ${ }^{87}$ The operation of bank distribution networks, which inevitably conflicts with the task of giving investment advice to customers ${ }^{88}$ is also forbidden by the conduct test. By eliminating such conflicts, the conduct test permits implementation of Glass-Steagall in the way most consistent with the intentions of Congress. ${ }^{89}$

\section{Public Confidence in the Commercial Banking System}

The conduct test would bolster public confidence in commercial banks because it prohibits the promotion of questionable securities in order to make an underwriting profit: Congress concluded that securities promotion, by "trading on the good name of the . . . bank," involves conduct that is incompatible with commercial banking. Default or deflation in the value of the securities recommended to a customer damages the reputation of the bank that recommends them, ${ }^{91}$ and is therefore not prudent commercial banking. The conduct test provides the guidelines necessary for determining which commercial bank activities are incompatible with Congress's intention to foster prudent banking behavior.

\section{Commercial Paper and Legitimate Commercial Banking Functions}

"Commercial paper" is the trade name for short term"2 promissory notes that financial and industrial corporations issue to raise capital..$^{93}$ Investment banks vigorously contest the legality of commercial paper sales by commercial banks, claiming that this activity violates the Glass-Steagall Act. ${ }^{94}$ Although the current method of interpreting the Act permits such sales, the conduct test would forbid them. ${ }^{95}$

business of banking; by discounting and negotiating . . . evidences of debt; by receiving deposits; by buying and selling exchange, coin and bullion; [and] by loaning money or personal security . . .." 12 U.S.C. § 24 (seventh) (1976).

87. See p. 104 supra; 75 CONG. REC. 9911 (remarks of Sen. Bulkley); 75 CONG. REG. 9999 (remarks of Sen. Kean).

88. See id.

89. See pp. 107-08 supra.

90. Hearings on the Operation of the National and Federal Reserve Banking Systems, Senate Banking and Currency Comm., S. 4115, 72d Cong., lst Sess., pt. 1, at 34 (1932); 75 CONG. REC. 9912 (1932) (remarks of Sen Bulkley).

91. Id.

92. Commercial paper must mature within nine months in order to be exempt from the registration provisions of the Securities Act of 1933, 15 U.S.C. $\$ 77 \mathrm{c}(\mathrm{a})(3)(1976)$.

93. See Hurley, supra note 23, at 525; Note, supra note 26, at 372.

94. See, e.g., A. G. Becker v. Board of Governors of Fed. Reserve Sys., No. 80-2614 (D.D.C., filed Oct. 14, 1980); Securities Indus. Ass'n v. Board of Governors of Fed. Reserve Sys., No. 80-2730 (D.D.C., filed Oct. 24, 1980).

95. Other similarly controversial bank activities include equity funding (the combined sale of mutual funds and insurance), real estate syndication, issuance of thrift notes, mortgage guarantee insurance underwriting, the deductible part of bankers' blanket bond insurance, dealings in bankers' ac- 


\section{A. The Controversy}

Commercial paper has become such an important source of short-term financing for publicly held corporations that the last five years have been characterized as the "commercial paper era." ${ }^{\text {"96 }}$ During this period, commercial paper has accounted for one quarter of all short-term debts outstanding." Consequently, the commercial paper market seriously encroaches on a traditional profit area of investment banks. ${ }^{98}$

Until July 26,1978, commercial paper was sold either directly by the issuing corporation, or by one of a handful of investment banks. ${ }^{99}$ Then Bankers Trust Company began selling third party commercial paper. ${ }^{100}$ On September 26, 1980, the Federal Reserve Board gave commercial paper sales an important stamp of legitimacy ${ }^{101}$ by concluding that commercial paper is not a "security" for the purposes of the Glass-Steagall Act, ${ }^{102}$ and that the Act therefore does not apply to commercial bank sales of commercial paper. The Federal Reserve Board ruling has prompted other large commercial banks to make final preparations to enter the commercial paper market. ${ }^{103}$

ceptances, investment advising, and portfolio investment advice.

96. J. P. Judd, Competition Between Commercial Paper Markets and Commercial Banks 39, 48 (Staff paper, Federal Reserve Bank of San Francisco on file with Yale Law Journal).

97. See id. at 48. Corporations generally prefer to raise cash by selling commercial paper rather than by borrowing from commercial banks, because the former usually costs less. The prime lending rate is often 125 basis points (1.25\%) higher than the average interest rate of 90 -day commercial paper. See id. at 39; Hurley, supra note 23, at 536 n.11. But see Bennett, supra note 9, at 1 (many commercial banks are cutting lending rates below prime to compete with commercial paper market).

98. See J. Judd, supra note 96, at 43. Profit on commercial paper comes from distribution commissions, which are typically one-eighth of one percent of the face value of the notes. Thus, if a bank sells $\$ 100$ million of a company's commercial paper, it makes $\$ 125,000$. See Hurley, supra note 23 , at 528.

99. As of October 1980, Moody's Commercial Paper Division listed over twenty investment banks in its dealer directory. MOODY'S COMMERCIAL PAPER RECORD, MONTHLY STATISTICAL SUPPLEMENT Oct. 1980, at 4. Most market observers, however, believe that six investment banks handle "well over $90 \%$ of the business." Interview with W. M. Thakara, Vice President, Commercial Paper New Issuer Development, A.G. Becker, Inc., in New York City (November 27, 1980).

100. H. Pitt \& J. Kempner, The Commercial Paper Activities of Bankers Trust Company 1-2 (February 1, 1979) (unpublished memorandum on behalf of A.G. Becker Inc. to the Staff of the Board of Governors of the Federal Reserve System) (on file with Yale Law Journal).

101. Federal Reserve Statement, supra note 72, at 7; Board of Governors of Fed. Reserve Sys. v. Investment Co. Inst., 101 S. Ct. 973, 981 n.21 (1981) (judgment of Board of Governors, because of their expertise, should be overturned only where no reasonable basis to support it); First Nat'l Bank v. Missouri, 263 U.S. 640,658 (1923) (courts must give great weight to construction of statute adopted by agency charged with its enforcement). The Federal Reserve Board has regulatory authority over state member banks of the Federal Reserve System. 12 U.S.C. $\S 1813$ (q)(2)(A) (1976). Bankers Trust Company is a state member bank of the Federal Reserve System. Bennett, supra note 9 , at 3 .

102. Federal Reserve Statement, supra note 72, at 6 (Glass-Steagall Act directs that definition of security be resolved by resort to common understanding of Congress, regulatory agencies, and banking industry).

103. See Bennett, supra note 9, at 1. Morgan Guaranty Trust Company and Citibank both have stated that they will begin placing commercial paper after the legal questions have been clarified. Id. There are indications that at least two other state member banks and two national banks intend to 


\section{B. The Present Interpretation of Glass-Steagall as Applied to Commer- cial Paper}

The Federal Reserve Board's interpretation of the Glass-Steagall Act fails to reflect important changes in the commercial paper market that place commercial banks in the posture of investment banks promoting the sale of investments. ${ }^{104}$ The Board's definitional approach frustrates the objectives of the Act.

\section{The Federal Reserve Board Interpretation}

The Federal Reserve Board takes the position that commercial paper is not a "security" within the meaning of the Glass-Steagall Act and therefore that the Act's prohibition of underwriting and dealing in securities does not apply to commercial paper. ${ }^{105}$ The Board arrived at its conclusion by examining the history of commercial paper in the United States. ${ }^{106}$ Using what it described as "indirect" historical evidence, ${ }^{107}$ the Board concluded that Congress did not view commercial paper, of the sort in existence when Glass-Steagall was passed, as a "security."

The Board's adoption of this definitional approach in regard to commercial paper has led it to conclude that it is not "necessary to examine the dangers that the Act was intended to eliminate." 109 The Board maintains this position even though it recognizes that such dangers exist ${ }^{110}$ and that the sale of commercial paper by commercial banks could lead to unsound banking practices. ${ }^{11}$ Rather than dispute the validity of the policies underlying Glass-Steagall, ${ }^{112}$ however, the Board seeks to regulate com-

begin underwriting commercial paper following the lead of Bankers Trust. SECURITIES WEEK, December 18, 1978, at 2.

104. See p. 115 supra.

105. See Federal Reserve Statement, supra note 72; Letter from Theodore E. Allison, Secretary of the Board of Governors of the Federal Reserve System, to John M. Liftin, attorney for the Securities Industry Association, and Harvey L. Pitt, attorney for A.G. Becker Inc. (September 26, 1980) (on file with Yale Law Journal).

106. See Letter, supra note 105.

107. See Federal Reserve Statement, supra note 72 , at 14.

108. Id.

109. Id. at 25 .

110. See Letter, supra note 105, at 3.

111. Id.

112. In order to justify its decision not to examine the policies behind Glass-Steagall, the Board cites Aaron v. SEC, 100 S. Ct. 1945, 1955 (1980), for the proposition that if the language of a provision of the securities laws is "clear in its context," it is unnecessary to examine additional considerations of policy that may have influenced the formulation of the statute. Federal Reserve Statement, supra note 72 , at $25 \& \mathrm{n} .38$. It is impossible to reconcile this statement with the Board's earlier statement that "the plain meaning of the statute cannot be dispositive of whether commercial paper is a security under the Glass-Steagall Act." See Federal Reserve Statement, supra note 72, at 25 (emphasis added).

The lack of a clear definition for the term "security" and the lack of any principled means for distinguishing between "loans" and "securities" demonstrate the futility of a purely textual approach 
mercial bank commercial paper activity, ${ }^{113}$ despite Congress's intention to enact a prophylactic remedy. ${ }^{114}$ The definitional approach taken by the Board, therefore, thwarts the policy objectives of Glass-Steagall because it applies a static method of inquiry to a financial market that has undergone a dramatic evolution over the last fifty years. ${ }^{115}$

\section{The Evolution of the Commercial Paper Market}

Today's commercial paper market is strikingly different from the one that existed when Glass-Steagall was written. ${ }^{116}$ The changes place banks in the promotional posture of an investment banker advocating the sale of an investment whenever they sell commercial paper. ${ }^{17}$

In the 1930's, when the securities laws were enacted, more than ninetynine percent of all commercial paper was purchased by commercial banks for their own investment portfolios. ${ }^{118}$ Commercial banks held this paper to maturity as an asset. ${ }^{119}$ The banks sought commercial paper in order to receive interest income and to satisfy the Federal Reserve Board's reserveasset requirement. ${ }^{120}$ Today, only about one percent of commercial paper is held by commercial banks for their own accounts. ${ }^{121}$ Trust departments of banks, ${ }^{122}$ nonfinancial corporations, insurance companies, private pen-

to Glass-Steagall controversies. See note 84 supra. This point presupposes that the Glass-Steagall Act does not define the term "security," a point acknowledged by the Federal Reserve Board, see Federal Reserve Statement, supra note 72, at 6, by the SEC, see Letter from Ralph C. Ferrara, General Counsel, Securities and Exchange Commission, to Neal L. Petersen, General Counsel, Board of Governors of the Federal Reserve System 3 (April 20, 1979), and by the Supreme Court, see Investment Co. Inst. v. Camp, 401 U.S. 617, 635 (1971). The teaching of Aaron v. SEC therefore is irrelevant in the context of determining whether a particular investment vehicle is a security for the purposes of the Glass-Steagall Act.

113. See Federal Reserve Statement, supra note 72 , at 25 (to prevent unsound banking practices, Board is developing "guidelines" governing sale of third-party commercial paper by commercial banks); $c f$. Letter, supra note 105, at 7 (Board regards banks' commercial paper activities as unquestionably prudent for sole reason that its examiners inspect banks).

114. See Investment Co. Inst. v. Camp, 401 U.S. 617, 639 (1971); pp. 107-09 supra.

115. See Note, supra note 26 , at 367 .

116. Id.

117. See, e.g., Bankers Trust Company Responds to your Commercial Paper Needs 4, 6 [hereinafter referred to as Bankers Trust Brochure] (undated, but copy is attached to February 1, 1979 memorandum from Fried, Frank, Harris, Shriver and Kampelman on behalf of A.G. Becker to Staff of the Board of the Federal Reserve System) (copies of both on file with Yale Law Journal).

118. R. Foulke, The COMmercial PAPER MARKet 11 (1931). Commercial paper was even defined in 1930 as "short term negotiable instruments sold to outside banking institutions." Id. at 3. 119. Id.

120. Banks that are members of the Federal Reserve System are required by the Federal Reserve Board to hold a certain percentage of deposits on reserve either uninvested or invested in certain highly liquid assets. U.S. BOARD OF GOVERNORS OF THE FEDERAL RESERVE SYSTEM, THE FEDERAL RESERVE SYSTEM 40 (5th ed. 1967).

121. See Hurley, supra note 23 , at 529 .

122. Trust accounts are customer accounts that a bank trust department administers on behalf of the customer. A bank trust department does not promote the sale of securities to the public; it promotes its expertise as fiduciary manager. Trust account purchases are separate and distinct from purchases for a bank's own account. 
sion funds, and, increasingly, private individuals now purchase commercial paper. ${ }^{123}$

\section{G. The Conduct Approach as Applied to Commercial Paper}

The commercial paper controversy demonstrates why the "conduct approach" provides a principled test with which to resolve Glass-Steagall controversies in today's quickly evolving financial markets. In the 1930's there was no danger that commercial banks would promote commercial paper and thereby cause the conflicts of interest that concerned the drafters of the Glass-Steagall Act. Commercial banks had not developed distribution systems for commercial paper. They participated in the commercial paper market to earn interest income, not commissions. Today they participate in the commercial paper market to earn distribution commissions. To earn these commissions requires exactly the promotional, investment banking conduct that Glass-Steagall was designed to foreclose to commercial banks. Commissions give commercial banks an incentive to promote one kind of investment over another. ${ }^{124}$ These commissions can be earned only by developing costly distribution systems. Once these distribution systems are established, banks must continuously cultivate both corporate issuers to create marketable debt, and purchasers to absorb that debt. ${ }^{125} \mathrm{Be}-$ cause commercial banks conduct themselves like investment banks in regard to commercial paper, the conduct test would prohibit commercial banks from selling such paper.

\section{Legitimate Commercial Banking Activity}

The Federal Reserve Board expressed concern that the acceptance of a definition of "security" broad enough to include commercial paper would lead to the prohibition of legitimate commercial banking activity. ${ }^{126}$ This

123. See Hurley, supra note 23 , at 529 .

124. See Letter from James J. Baechle's Senior Vice President and General Counsel, Bankers Trust Company, to Neal L. Petersen, General Counsel, Board of Governors of the Federal Reserve System (December 22, 1978) (on file with Yale Law Journal).

Bankers Trust Company, the only bank with an established commercial paper sales operation, acknowledges that all of the corporations for which it distributes commercial paper were customers of the bank before the commercial paper services were offered. These corporations remain loan customers of the bank, and as such are indebted to the bank at the same time the bank is selling the corporation's commercial paper. Id. Consequently, the temptation to convince a corporate customer to issue corporate debt unnecessarily, or to pay back outstanding bank loans, is present here. In addition, Bankers Trust Company had lines of credit in place to most of the issuers that currently use Bankers Trust Company's commercial paper distribution services. Id.

125. Distribution channels are crucial to the success of a firm that hopes to win a share of the commercial paper market. The Bankers Trust commercial paper advertising materials demonstrate that widespread distribution is a major element in its commercial paper marketing approach. See Bankers Trust Brochure, supra note 117, at 1-5.

126. Commercial banks may engage in activities that are "a proper incident of banking" unless 
concern applies specifically to certificates of deposit, ${ }^{127}$ banker's acceptances, ${ }^{128}$ and loan participations. ${ }^{129}$ The conduct test does not lead to the prohibition of commercial bank involvement in these activities. Instead it illuminates the basic distinction between these transactions and modern commercial paper financings. In each of these transactions, banks are the ultimate lender or borrower. The transactions do not promote the development of distribution networks or place banks in a position where they will put pressure on corporate clients to issue securities for the purpose of realizing underwriting or distribution profits. Instead, trading or distribution is only incidental to commercial bank lending services. ${ }^{130}$

The congressional ban on commercial banks' promotion of securities applies when distribution commissions provide the motivation for entering the market, as in the case of commercial paper. When commercial banks

that activity violates $\S 16$ of the Glass-Steagall Act. Fed. Reserve Sys. v. Investment Co. Inst., $101 \mathrm{~S}$. Ct. 973,979 (1981); 12 C.F.R $\S 225.125$. The commercial banks that advised the closed-end investment funds at the center of the Board of Governors litigation earned an "advisory fee" for providing investment advice to the investment companies. $101 \mathrm{~S}$. Ct. at 979 . This advisory fee differs significantly from the sale or distribution commissions earned by promoting investments as described by the conduct test. In the case of the advisory fee "[the] bank could not stray from its obligation to render impartial investment advice." Id. at 987 n.39. Banks engaged in activity that violates the conduct test necessarily stray from their obligation to render disinterested investment advice, and therefore violate $\S 16$ of the Glass-Steagall Act. See pp. 112-13 supra.

127. A certificate of deposit is a written acknowledgment by a bank of the receipt of a sum of money on deposit that the bank agrees to pay (with specified interest) to the bearer at a later date. 1 BANKING L.J., BANKING LAW JOURNAL DIGEST $\S 220$ (6th ed. 1962). A certificate of deposit is similar to a savings deposit at a bank except that it has a fixed maturity date and is evidenced by a certificate instead of a passbook entry. G. MUNN, ENCYCLOPEDIA OF BANKING AND FINANCE 144-45 (4th ed. 1937). The banking practices of issuing certificates of deposit and discounting them are specifically authorized by the Glass-Steagall Act. See 12 U.S.C. $\S 24$ (seventh) (1976).

128. A banker's acceptance is a guarantee by a commercial bank that its customer will pay for goods purchased on credit. It is identical to a guaranteed line of credit, except that the goods purchased serve as collateral for the bank. Banker's acceptances expedite transactions in which the contracting parties are unfamiliar with each other but have confidence in the bank's guarantees. See 1 BANkING L.J., supra note 127; G. MUNN, supra note 127, at 47-48.

129. See note 83 supra. Loan participations provide an example of how the traditional interpretation of Glass-Steagall could serve to prohibit commercial banks from engaging in permissible conduct. The Securities and Exchange Commission has recently written that "absent greater elaboration, sales of loan participations may raise questions under the Glass-Steagall Act." See Letter from Ralph C. Ferrara, General Counsel to the Securities and Exchange Commission, to Neal L. Petersen, General Counsel to the Board of Governors of the Federal Reserve System 6 (June 26, 1979) (on file with Yale Law Journal). The SEC reached this conclusion because of its view that the broad definition of "security" in the Securities Act of 1933 is appropriate for use in interpreting the Glass-Steagall Act. Id.

130. There is an important distinction for Glass-Steagall purposes between transactions in which a commercial bank sells a note that it intends to guarantee and redeem, as in the case of a banker's acceptance or a certificate of deposit, and a transaction in which the bank sells a note in order to earn a commission, with no obligation to guarantec the payment, as in the case of the sale of commercial paper. In the former case, no conflicts of interest are likely to exist. If the commercial banker must guarantee the full payment of any default, his investment advice will undoubtedly be based solely on sound business judgment. Similarly, there is no danger that the commercial banker will be tempted to promote a securities issue and use the proceeds to pay back bank loans if the bank is at risk in both transactions. Thus, none of the conflicts that arise when banks sell commercial paper arise when banks issue certificates of deposit or bankers acceptances. See pp. 104-06 supra. 
are primarily guaranteeing credit, ${ }^{131}$ taking deposits, ${ }^{132}$ or making loans, ${ }^{133}$ Glass-Steagall proscriptions should not apply. Unlike the sale of commercial paper, these activities do not entail conduct that is incompatible with the purposes of the Glass-Steagall Act.

\section{Conclusion}

The conduct approach proposed in this Note provides a principled method for determining when commercial banks are violating the GlassSteagall Act. The current use of a technical rather than a substantive method of resolving Glass-Steagall disputes has eroded the barrier that the Act seeks to build between commercial and investment banking. The adoption of the conduct test will ensure that legitimate commercial banking activity will not be endangered by overzealous regulatory agencies misapplying the Act. The conduct approach will also provide the flexibility necessary for the Act to keep pace with the swift evolution of financial instruments and markets.

131. See note 128 supra.

132. See note 127 supra.

133. See notes 83 and 129 supra. 